\title{
COMPARING THE EFFICIENCY IN DNA EXTRACTION BETWEEN ORGANIC PHENOL AND MAGNETIC BEADS METHODS
}

\author{
Nermien A. Ibrahim ${ }^{1}$ Samir A. Nassar ${ }^{2}$ Ali M. Abd El-Gawad ${ }^{2}$ Mohamed F. \\ Omar $^{2}$ \\ Department of Forensic Medicine and Clinical Toxicology ${ }^{1}$, Faculty of Medicine, \\ Zagazig University, Egypt, Zoology'2, Faculty of Science, Zagazig University, \\ Egypt.
}

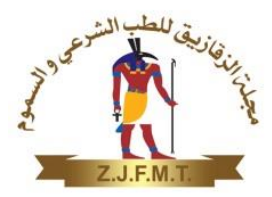

\begin{abstract}
Introduction: Deoxyribonucleic acid (DNA) extraction is a fundamental step in any forensic analysis procedure. Selecting an extraction method to yield DNA is suitable in quality and quantity is, also, crucial. Aim: The objective of this study is to evaluate the adequateness of two DNA extraction methods regarding the DNA quality \& quantity, and the time \& money costs. Materials \& Methods: The first method is the organic phenol extraction method, while the second is the automated magnetic beads extraction technology. The DNA quality and quantity were assessed by the NanoDrop ND-1000 spectrophotometer. Results: Organic phenol extraction, significantly, yielded more DNA in quantity than the magnetic beads methods. However, non-significant difference was detected in the quality of the DNA yielded from the two methods as measured by NanoDrop ND-1000 spectrophotometer. Organic phenol extraction consumed far more time but much less money than the magnetic beads method. Conclusion: Accordingly, magnetic beads technology is more efficient DNA extraction method than organic phenol extraction in saving time, effort and lab safety. On the other hand, organic phenol extraction is more economic and efficient in the quantity of the DNA yielded. However, both methods yielded the same quality of the extracted DNA. Automation saves much time than manual techniques.
\end{abstract}

Keywords: Organic Phenol Extraction; Magnetic Beads Technology; DNA quality and quantity.

Corresponding Author:

Nermien A. Ibrahim: Department of Forensic Medicine and Clinical Toxicology, Faculty of Medicine, Zagazig University, Egypt

Email: nooredo@gmail.com

\section{INTRODUCTION}

F orensic Evidence containing DNA is instrumental in helping to identify and convict/exonerate a certain suspect (1). Choosing the right techniques is crucial to having optimal results in the forensic analysis of trace DNA evidence (2). Different protocols for DNA extraction have been used extensively, but the choice of the applied method is a result of the balance among three major principles that can be in conflict with one other i.e. The combination of (1) the highest endogenous DNA yield with (2) the lowest co-purification of other chemical components at (3) the most time and cost efficient way. From a forensic laboratoro management perspective, the ultimate protocol should be able to show the optimal balance among these three principles to handle a large number of samples in a short time (3).

Deoxyribonucleic acid extraction protocols depend on the use of chemicals such as phenol-chloroform, sodium hydroxide $(\mathrm{NaOH})$, or already prepared kits and a manual describing step-by-step instruction for extracting DNA. Due to practical and methodological reasons, however, it is important to compare the yield and purity of DNA obtained by different methods (4).

Organic DNA extraction, sometimes referred to as phenol-chloroform extraction, has been in use for the longest period of time, and may be used for situations where either restriction fragment length polymorphism (RFLP) or polymerase chain reaction (PCR) typing is performed. High-molecular-weight DNA, which was essential for early RFLP methods, 
may be obtained most effectively with organic extraction (5).

For "Magnetic Beads Methods', according to Wenlong et al. (6), the principle is the destruction of cells by using a protein denaturation agent, hence, the free release of DNA. Then comes the role of magnetic beads that specifically adsorb nucleic acid. A high purified and concentrated of DNA is obtained and used for PCR template, genetic engineering, gene chip technology.

Phenol-chloroform extraction proved to be a well-established forensic extraction procedure and the method of choice for samples containing only very little amounts of DNA, but it is known to be laborious with the involvement of toxic reagents, such as phenol. Accordingly, this study aims to compare the efficiency of phenol-chloroform extraction method with the automated magnetic beads method regarding the cost, time and DNA concentration.

\section{Subjects}

\section{SUBJECTS AND METHODS}

The population samples have been collected from 45 unrelated volunteers from both sexes (18 males and 27 females), age ranged from 20-40 years. Buccal swab samples were processed in the Central Laboratory, Faculty of Medicine, Zagazig University, Egypt.

The study was approved by the Local Ethics Committee in the Faculty of Medicine, Zagazig University, Egypt, and an informed consent was taken from the volunteers after explaining the method for sample collection and aim of the study.

\section{Methods}

\section{1- $\quad$ Sample Collection and Processing:}

Buccal swabs are the least invasive way for collecting DNA from human, and also have the added benefit of minimizing the exposure to blood-borne pathogens. The volunteers recruited were asked to rinse their mouth with tap water, 30 seconds before sampling of buccal swabs, to avoid the contamination as a result of food particles. For each individual, both sides of buccal mucosa were wiped with a cotton swab for 15 seconds. Two buccal swap samples were donated from each volunteer. Samples were collected in $500 \mathrm{ul}$ 10 M Tris-hydrochloric acid (Tris- $\mathrm{HCl}$ ), 10 $\mathrm{mM}$ ethylene diamine tetra acetate (EDTA), $2 \%$ sodium dodecyl sulfate (SDS), containing 1.5-ml microcentrifuge tubes (7). Then, extraction of DNA from cotton swabs was performed.

\section{2- Organic DNA-Extraction Method:}

Phenol-chloroform extraction method involves the sequential addition of several chemicals. In general, this method involves disruption and lysis of the stain material, digestion of cell components and removal of contaminants by organic solvents. The DNA is finally recovered by alcohol and salt precipitation and subsequent rehydration. The detailed procedure is referred to the study of Sambrook et al. (8). Figure-1 summarizes the steps for organic phenol extraction from buccal swab cells (9).

\section{3- Magnetic Beads Method:}

This purification method depends on binding of DNA to silica-coated magnetic beads in the presence of chaotropic salts such as guanidine hydrochloride, sodium iodide and sodium perchlorate. The beads were separated from the lysate using a magnet. The DNA was then washed and eluted in Tris-EDTA buffer (10 $\mathrm{mM}$ Tris- $\mathrm{HCl}, 1 \mathrm{mM}$ EDTA $\mathrm{pH}$ 8). The detailed procedure is referred to the study of Montpetit et al. (10). This method is done using the automated BioRobot EZ1® Technology, Egypt, according to the manufacturer handbook. Figure-2 summarizes the steps for BioRobot ${ }^{\circledR}$ EZ1 method from buccal swab cells (9). 

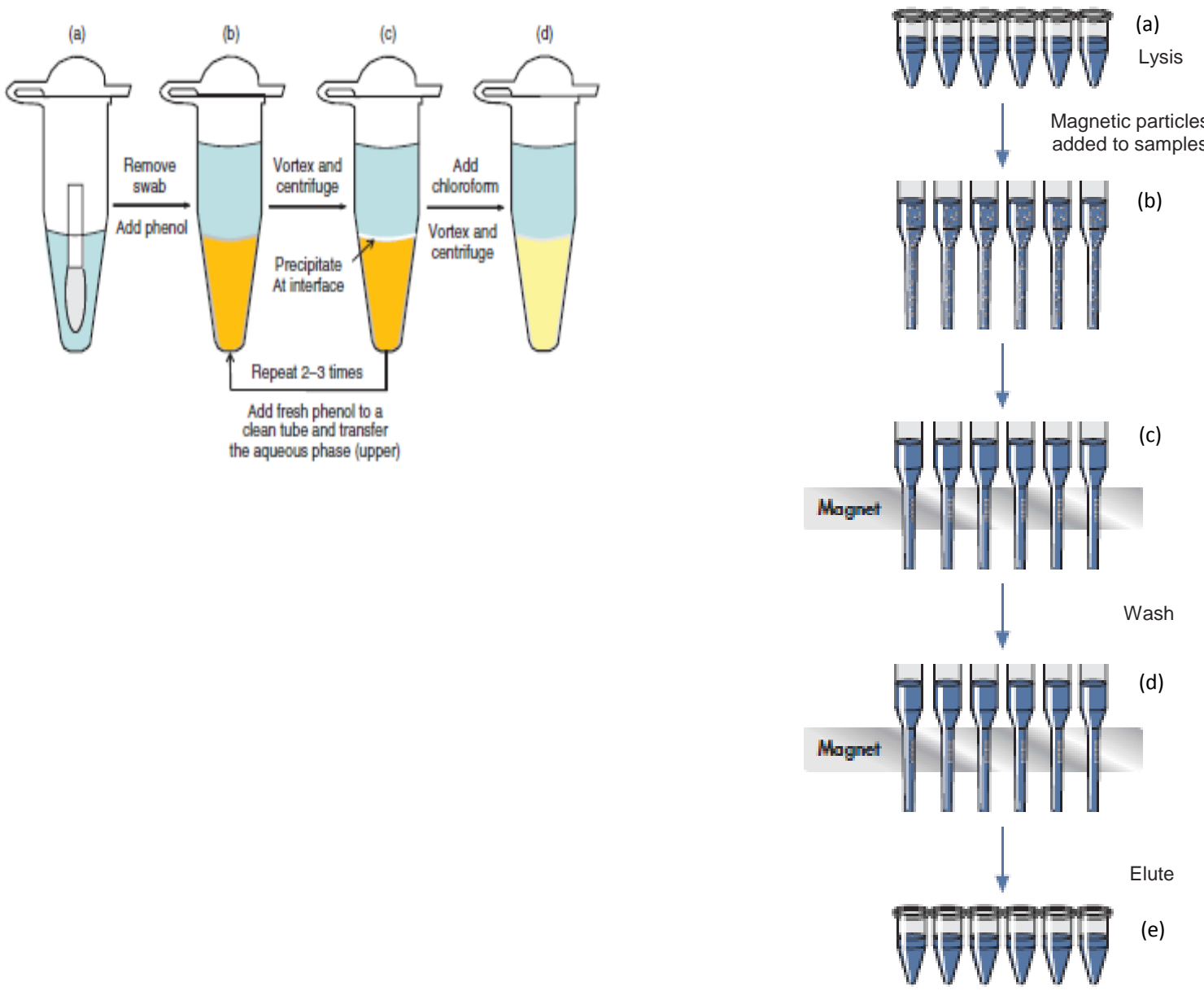

Figure-1: DNA extraction from a buccal swab cells using a salting-out method based on phenol-chloroform. (a) Cellular material is added to a lysis buffer and proteinase $\mathrm{K}$ and incubated at $56{ }^{\circ} \mathrm{C}$ for at least 15 minutes. (b and c) The swab is removed and phenol is added, the solution is then vortexed and centrifuged. Precipitated protein and carbohydrate form a pellicle at the interface; this step is repeated until there is no visible material at the interface. Protocols vary - some use only phenol, others phenol and chloroform (isoamyl alcohol may be added to the phenol/chloroform mixture to prevent it separating). (d) In a final step chloroform alone is added; this removes any residual phenol, which would inhibit downstream processes such as PCR. The aqueous phase now contains DNA (9).

\section{4- Quality and Quantity of the Extracted} DNA:

Deoxyribonucleic acid quantity and quality were assessed by NanoDrop ND-1000 spectrophotometer (NanoDrop Technologies Inc., Wilmington, Delaware, USA). Absorbance was measured at wavelengths of 260 and $280\left(\mathrm{~A}_{260}\right.$ and $\mathrm{A}_{280}$, respectively) $\mathrm{nm}$. The absorbance quotient (OD260/OD280)

Figure-2: Automated magnetic beads DNA extraction method. (a) Digested cells from buccal swabs (b) DNA binds to magnetic particles (c-d) Magnetic separation (e) Pure and high-quality DNA (11). provides an estimate of DNA purity. An absorbance quotient value of $1.8<$ ratio $(\mathrm{R})<$ 2.0 was considered to be good, purified DNA. A ratio of $<1.8$ is indicative of protein contamination, where as a ratio of $>2.0$ indicates ribonucleic acid (RNA) contamination. Samples were stored at $-20{ }^{\circ} \mathrm{C}$ until analysis (7).

5- $\quad$ Statistical Analysis: 
Deoxyribonucleic acid yield was measured in $\mathrm{mg} / \mathrm{ml}$. Data were analyzed using SPSS version 19. Student $T$ test was applied to measure the significant differences between the DNA yield from the two used extraction methods. Differences were considered significant when $\mathrm{p}<0.05$.

\section{RESULTS}

- Demographic Characters for the volunteers: The age and sex of the 45 volunteers are presented in the following table.

Table-1: Demographic characters of the 45 unrelated volunteers:

\begin{tabular}{|c|c|c|c|}
\hline \multirow{2}{*}{ Age Range } & \multicolumn{3}{|c|}{ Number of Participants } \\
\hline & Male & Female & Total \\
\hline From 20-25 & 4 & 3 & 7 \\
\hline From 26-30 & 5 & 10 & 15 \\
\hline From 31-35 & 5 & - & 5 \\
\hline From 36-40 & 4 & 14 & 18 \\
\hline Total & 18 & 27 & 45 \\
\hline
\end{tabular}

Quantity of Extracted DNA (DNA According to spectrophotometer 260/280 nm

\section{Concentration):}

The DNA concentration in $\mathrm{mg} / \mathrm{ml}$ for the 45 volunteers by both the organic extraction method and magnetic beads extraction method are presented in table-2. The mean value of DNA yield using the organic extraction method was $31.40 \pm 3.25 \mathrm{mg} / \mathrm{ml}$, which showed significant increase $(\mathrm{p}<0.05)$ compared to the mean value of DNA yield using the magnetic beads method was $16.06 \pm$ $3.49 \mathrm{mg} / \mathrm{ml}$ (Table-3, Figure-3).

- Quality of the Extracted DNA: absorbance ratio, DNA extracted from both extraction methods showed an absorbance ratio above 1.8 and below 2, which is considered to be pure and high quality DNA. Non-significant difference $(p>0.05)$ was detected in the absorbance between the organic and magnetic beads extraction methods.

\section{- Time and Money Cost:}

Table-4 presents money cost in Egyptian pound (LE) per sample and the time spent in processing the samples for each used extraction method.

Table-4: Deoxyribonucleic acid concentration in terms of $\mathbf{m g} / \mathbf{m l}$ for the 45 volunteers using organic extraction and magnetic beads extraction methods

\begin{tabular}{|l|c|c|}
\hline \multicolumn{1}{|c|}{ Extraction Method } & Time in min/Sample & Money in L.E./Sample \\
\hline Organic Phenol & 95 & 90 LE \\
\hline Magnetic Beads & 35 & 250 LE \\
\hline
\end{tabular}


Table-2: Deoxyribonucleic acid concentration in terms of $\mathrm{mg} / \mathrm{ml}$ for the 45 volunteers using organic extraction and magnetic beads extraction methods

\begin{tabular}{|c|c|c|}
\hline \multirow[t]{2}{*}{ Sample $\mathrm{N}^{\circ}$} & \multicolumn{2}{|c|}{ Deoxyribonucleic acid Concentration in $\mathrm{mg} / \mathrm{ml}$} \\
\hline & Organic Extraction Method & Magnetic Beads Extraction Method \\
\hline 1 & 32.85 & 16.53 \\
\hline 2 & 28.77 & 14.13 \\
\hline 3 & 36.17 & 12.22 \\
\hline 4 & 31.52 & 17.82 \\
\hline 5 & 29.74 & 14.54 \\
\hline 6 & 36.46 & 26.77 \\
\hline 7 & 34.74 & 13.32 \\
\hline 8 & 22.72 & 11.63 \\
\hline 9 & 31.79 & 19.12 \\
\hline (Table ) Continued) & 25.44 & 20.18 \\
\hline 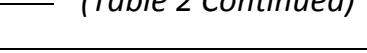 & 32.12 & 15.33 \\
\hline 12 & 33.87 & 19.46 \\
\hline 13 & 37.22 & 18.95 \\
\hline 14 & 27.47 & 9.88 \\
\hline 15 & 31.11 & 14.64 \\
\hline 16 & 31.32 & 16.87 \\
\hline 17 & 29.55 & 16.34 \\
\hline 18 & 26.55 & 23.12 \\
\hline 19 & 34.54 & 11.86 \\
\hline 20 & 34.52 & 17.22 \\
\hline 21 & 33.91 & 18.64 \\
\hline 22 & 29.14 & 16.85 \\
\hline 23 & 33.15 & 11.65 \\
\hline 24 & 31.57 & 18.12 \\
\hline 25 & 28.56 & 15.24 \\
\hline 26 & 33.48 & 16.29 \\
\hline 27 & 35.32 & 17.25 \\
\hline 28 & 30.87 & 13.58 \\
\hline 29 & 30.47 & 15.47 \\
\hline 30 & 32.84 & 17.56 \\
\hline 31 & 28.12 & 12.95 \\
\hline 32 & 31.52 & 17.24 \\
\hline 33 & 29.14 & 11.58 \\
\hline 34 & 31.44 & 16.24 \\
\hline 35 & 30.47 & 15.47 \\
\hline 36 & 32.45 & 13.54 \\
\hline 37 & 35.24 & 18.55 \\
\hline 38 & 32.87 & 16.27 \\
\hline 39 & 30.74 & 17.21 \\
\hline 40 & 23.45 & 10.54 \\
\hline 41 & 27.74 & 9.55 \\
\hline 42 & 34.79 & 22.15 \\
\hline 43 & 34.74 & 19.62 \\
\hline 44 & 31.44 & 14.12 \\
\hline 45 & 31.17 & 17.32 \\
\hline
\end{tabular}


Table-3: Comparison between the mean DNA concentration in $\mathrm{mg} / \mathrm{ml}$ expressed in means \pm SD for the 45 volunteers using organic extraction and magnetic beads extraction methods

\begin{tabular}{|c|c|c|c|}
\hline \multirow{2}{*}{ Method } & \multicolumn{2}{|c|}{ DNA Concentration in $\mathrm{mg} / \mathrm{ml}$} & \multirow{2}{*}{ p-value } \\
\cline { 2 - 3 } & $\begin{array}{c}\text { Organic } \\
\text { Extraction } \\
\text { Method }\end{array}$ & $\begin{array}{c}\text { Magnetic Beads } \\
\text { Extraction } \\
\text { Method }\end{array}$ & \\
\hline $\mathrm{X} \pm$ SD & $31.40 \pm 3.25$ & $16.06 \pm 3.49$ & \multirow{2}{*}{0.000} \\
\hline $\mathrm{t}-$ value & 64.809 & 30.827 & \\
\hline
\end{tabular}

\section{X: Mean SD: Standard Deviation}

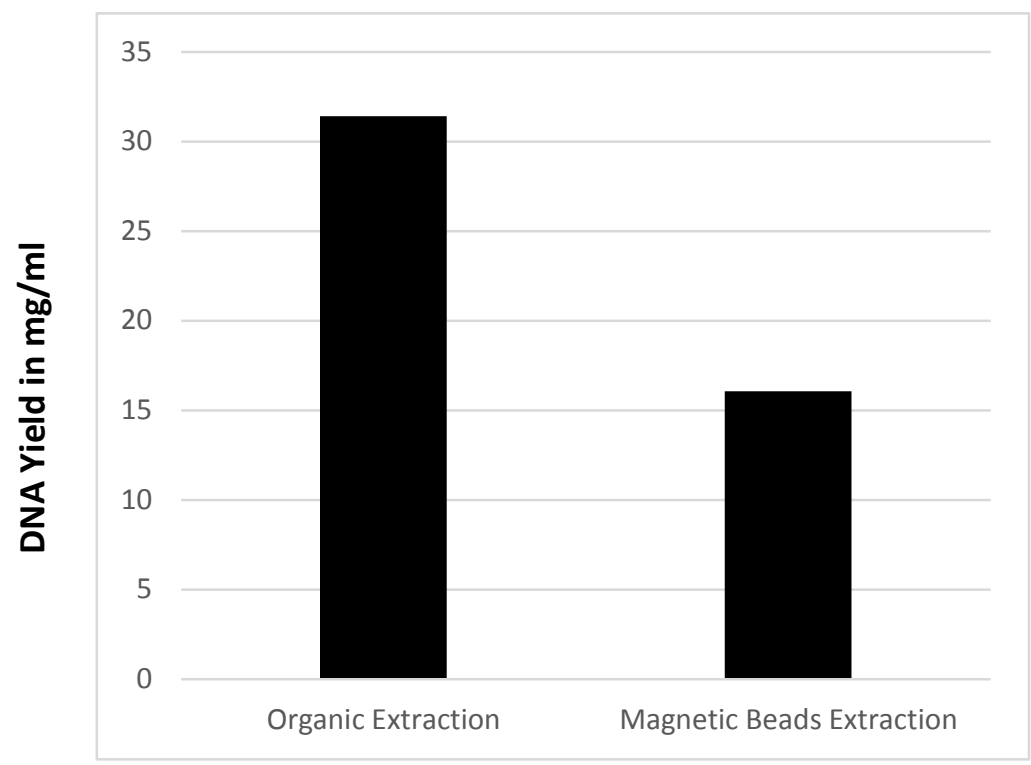

DNA Extraction Methods

Figure-3: The mean DNA yield in $\mathrm{mg} / \mathrm{ml}$ manual organic extraction and automated magnetic beads extraction methods

\section{DISCUSSION}

The present study offers a comparison between two DNA extraction methods regarding DNA quantity \& quality, time consumption and money cost. Sampling was applied through buccal swaps. The successful use of buccal cells as a DNA source has been reported for many studies for several reasons, including: 1) easy and noninvasive method for obtaining samples; 2) only simple implements, such as cytologic brush, required, and 3) reliable test results for screening (12), (13) and (4).

Regarding the DNA quality and quantity, it's still controversial, which extraction method and whether manual or automated technique, would provide more
DNA suitable in quantity and quality for further fingerprinting procedures. In the present study, the mean DNA concentration from manual organic phenol extraction showed a significant increase compared to the mean DNA concentration from automated magnetic beads technology, with nonsignificant difference in the DNA quality between the 2 extraction methods. Several studies have showed that organic extraction method (Phenol/Chloroform) yielded more DNA concentration compared other techniques/kits, as PrepFiler® DNA extraction kit and QIAamp ${ }^{\circledR}$ DNA investigator kit (14) and iPrep Forensic Kit (2). 
The same results, as the current study, were reported several years ago by CaldarelliStefano et al. (15) and Scott et al. (16) stated that organic extraction method yielded more DNA concentration than magnetic beads technology. Recently, Eychner et al. (17) stated that the organic phenol-chloroform DNA extraction method is considered the oldest and "gold standard" method for obtaining high molecular weight, and it yields the highest quantity of DNA using standard samples. For samples coming from old bones, the best DNA yield was achieved by the organic phenol/chloroform extraction method as reported by Kus et al. (14).

On the other hand, Abd El-Aal et al. (18) recommended the use of magnetic DNA separation for several reasons as its high quality nucleic acid extraction, reduced risk of cross-contamination, minimal required starting material, cost-effective, user friendly, and can be optionally automated.

Psifidi et al. (19) reported, by comparing eleven DNA extraction methods, that measurements revealed that the magnetic beads based protocol extracted the most concentrated DNA, followed by the phenolchloroform protocols. For the DNA quality the same authors reported that magnetic beads based protocol was more efficient the organic phenol extraction, for extracting high quality and quantity DNA suitable for large-scale microarray genotyping and also for long-term DNA storage. This difference can be attributed to their use of blood samples in their study instead of buccal swabs as in the current study.

Regarding automating the extraction techniques, Riemann et al., (20) and Kalmar et al. (21) proved in their studied that manual DNA extraction techniques were found to be superior in terms of extracted DNA quantity and quality than automated ones. The first study used whole blood, while the second study used biopsy tissues and formalin-fixed, paraffin-embedded.

Handling time and cost interfere in selecting the most suitable DNA extraction method (22). Regarding saving time, effort and money consumption, automated magnetic beads technology showed more efficiency in
DNA extraction than organic phenol extraction, while organic phenol extraction was more economic regarding money cost. These findings were the same as the study of Psifidi et al. (19) who reported that the most time-consuming was the phenol-chloroform protocol, while the magnetic beads developed protocol had intermediate time requirements, also, phenol-chloroform protocol was the cheapest, most technically difficult to perform and required the use of highly toxic phenol.

\section{CONCLUSION}

Forensic labs have the responsibility to select the most appropriate DNA extraction method regarding DNA quality \& quantity, time and money consumption, and the effort required. According to the current study, the manual organic DNA extraction method proved to be economical and an efficient method regarding quality \& quantity of the extracted DNA, but its time consuming and laborious. On the other hand, automated magnetic beads technique extracted the same DNA quality but less in quantity and costed much money. In the same time, it proved to be more efficient regarding time and effort.

DNA extraction in forensic practices needs the best available and affordable technique that is capable to yield the most adequate DNA quality \& quantity. Organic phenol extraction method fulfils the most important selection criteria; accordingly, it's recommended to carry out more research to overcome the laborious steps and time waste. Besides, more accurate implementation for lab safety measures to avoid the hazards from dealing with phenol and other chemicals.

\section{REFERENCES}

1- Kuperus, W.R.; Hummel, K.H.; Roney, J.M.; et al. (2003): Crime scene links through DNA evidence: the practical experience from Saskatchewan casework. Canadian Society Forensic Science Journal; 36: 19-28.

2- Stoopa, B.; Defauxb, P.; Utza, S and Ziegera, M. (2017): Touch DNA sampling with SceneSafe Fast $^{\mathrm{TM}}$ minitapes. Legal Medicine; 29: 68-71. http://dx.doi.org/10.1016/j.legalmed.2017.10.006

3- Desmyter, S.; De Cock, G. and Moulin, S. (2017): Fabrice Noël. Organic extraction of bone lysates improves DNA purification with silica beads. Forensic Science International; 273: 96101.

http://dx.doi.org/10.1016/j.forsciint.2017.02.003 
4- Chengl, T.; Chenl, S.; Lu, T.; Chen, W.; Sher, J. and Shieb, Y. (2010): Optimal DNA Extraction from Buccal Swab Samples. Journal of Medical Sciences; 30(4): 149-154. http://jms.ndmctsgh.edu.tw/3004149.pdf

5- Comey, C., Koons, B., Presley, K., Smerick, J., Sobieralski, C., Stanley, D., and Baechtel, F. (1994): DNA Extraction Strategies for Amplified Fragment Length Polymorphism Analysis. Journal of Forensic Science; 39(5): 1254-69.

6- Wenlong, Y.; Zhanhai, K.; Bu, T.; et al. (2010): Gene chip technology and its application in plants. Anhui Agricultural Science; 38(26): 14279-80.

7- Ghatak, S.; Muthukumaran, R. and Nachimuthu, S. (2013): A Simple Method of Genomic DNA Extraction from Human Samples for PCR-RFLP Analysis. Journal of Biomolecular Techniques; 24(4): 224-31.

8- Sambrook, J., Fritsch E., and Maniatis, T. (1989): Molecular Cloning: A Laboratory Manual, 2nd ed., Cold Spring Harbor Laboratory Press, Cold Spring Harbor, NY.

9- Goodwin, W.; Linacre, A. and Hadi S. (2011): DNA Extraction and Quantification. In: An Introduction to Forensic Genetics (William Goodwin, Adrian Linacre, Sibte Hadi) eds, $2^{\text {nd }}$ ed, John Wiley \& Sons Ltd, pp 37-52.

10- Montpetit, S.A.; Fitch, I.T. and O'Donnell, P.T. (2005): A simple automated instrument for DNA extraction in Forensic Casework. Journal of Forensic Sciences; 50(3):1-9.

11- QIAGEN (2007): BioRobot ${ }^{\circledR}$ EZ1 DSP Workstation User Manual; QIAGEN GmbH, D40724 Hilden.

http://www.qiagen.com/eg/resources/resourcedetail?i $\mathrm{d}=1 \mathrm{dd} 1 \mathrm{c5eb}-\mathrm{ac} 07-4212-8114-$

a42b3b3ecb65\&lang=en\&autoSuggest $=$ true

12- Thomson, D.M.; Brown, N.N. and Clague, A.E. (1992): Routine use of hair root or buccal swab specimens for PCR analysis: advantages over using blood. Clin Chim Acta; 207: 169-74.

13- Christofolini, D.M.; Lipay, M.V.; Ramos, M.A.; Brunoni, D. and Melaragno, M.I. (2006): Screening for fragile $\mathrm{X}$ syndrome among Brazilian mentally retarded male patients using PCR from buccal cell DNA. Genetic Molecular Research; 5:448-53.

14- Ku, M.; Ossowski, A. and Zielinska, G. (2016): Comparison of three different DNA extraction methods from a highly degraded biological material. Journal of Forensic and Legal Medicine; 40: 47-53. http://dx.doi.org/10.1016/j.jflm.2016.03.002

15- Caldarelli-Stefano, R.; Vago, L.; Bonetto, S.; Nebuloni, M. and Costanzi, G. (1999): Use of magnetic bead for tissue DNA extraction and
IS6110 Mycobacterium tuberculosis PCR. Journal Clininical Patholology; 52:158-63.

16- Scott, D.L.; Clark, C.W.; Tooley, P.W.; Carras, M.M. and Maas, J.L. (2000): The use of biomagnetic separation to recover DNA suitable for PCR from Claviceps species. Letter of Applied Microbiology; 31:95-9.

17- Eychner, A.; Schott, K. and Elkins, K. (2017): Assessing DNA recovery from chewing gum. Medicine, Science and the Law; 57(1): 7-11.

18- Abd El-Aal, A.; Abd Elghany, N.; Mohamadin, A. and El-Badry, A. (2010): Comparative study of five methods for DNA extraction from whole blood samples. International Journal of Health Science; III(1): 285-87.

19- Psifidi, A.; Dovas, C.I.; Bramis, G.; Lazou, T.; Russel, C.L.; Arsenos, G.; et al. (2015): Comparison of Eleven Methods for Genomic DNA Extraction Suitable for Large-Scale WholeGenome Genotyping and Long-Term DNA Banking Using Blood Samples. PLoS ONE 10(1): e0115960. doi:10.1371/journal. pone. 0115960

20- Riemann, K.; Adamzik, M.; Frauenrath, S.; et al. (2007): Comparison of Manual and Automated Nucleic Acid Extraction from Whole-Blood Samples. Journal of Clinical Laboratory Analysis; 21: 244-8.

21- Kalmár, A.; Péterfia, B.; Wichmann, B.; Patai, Á.; Barták, B.; Nagy, Z.; Furi, I.; Tulassay, Z. and Molnár, B. (2015): Comparison of Automated and Manual DNA Isolation Methods for DNA Methylation Analysis of Biopsy, Fresh Frozen, and Formalin-Fixed, Paraffin- Embedded Colorectal Cancer Samples. Journal of Laboratory Automation; 20(6): 642-51.

22- Marsal, G.; Boronat, N.; Canals, J.; Zamora, F. and Fort, F. (2013): Comparison of the efficiency of some of the most usual DNA extraction methods for woody plants in different tissues of Vitis Viniferal L. The Journal International des Sciences de la Vigne et du Vin; 47(4): 227-37. 